\title{
Changing Temperature Affects Anesthetic Effects and Physiological Stress Responses in Marine Medaka, Oryzias dancena
}

\author{
In-Seok PARK ${ }^{\dagger} \cdot$ Young-Ju KIM ${ }^{*} \cdot$ In-Bon GOO ${ }^{* *} \cdot$ Hee-Jung $\mathrm{KONG}^{* *} \cdot$ Bong-Seok KIM ${ }^{* *}$ \\ $\left({ }^{\dagger^{*}}\right.$ Korea Maritime and Ocean University $~^{* *}$ National Fisheries Research \& Development Institute)
}

\author{
해산송사리, Oryzias dancena의 수온 변화에 의한 마취 효과와 \\ 생리적 스트레스 반응

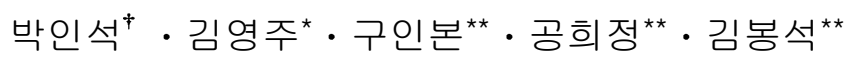 \\ ( ${ }^{*}$ 한국해양대학교 $\cdot{ }^{* *}$ 국립수산과학원 $)$
}

\begin{abstract}
본 연구는 온도 변화에 따른 해산송사리, Oryzias dancena의 마취 효과 및 생리적 스트레스 반응 을 평가하고, 고온 및 저온에서 최적의 마취 수온을 구명하였다. 해산송사리에서 고온 실험 $\left(36-42^{\circ} \mathrm{C}\right)$ 과 저온 실험 $\left(4 \sim 10^{\circ} \mathrm{C}\right)$ 을 통해 마취 효과를 조사하였으며, 각 마취수온에서 전어체의 cortisol과 glucose를 측정하였다. 각 수온 마취 실험 후, 전개체는 모두 생존하였으며, 해산송사리의 마취시간은 고온 실 험에서 고온 일수록, 저온 실험에서는 저온 일수록 유의적으로 빨랐다 $(P<0.05)$. 회복 시간은 유의하 게 고온 실험에서 수온이 감소할수록, 저온 실험에서는 수온이 증가할수록 유의적으로 느렸다 $(P<0.05)$. 아가미 운동수는, 고온 실험에서 수온이 증가함에 따라 빨랐으며, 저온 실험에서는 수온이 감소할때 빨랐다 $(P<0.05)$. 수온이 $38^{\circ} \mathrm{C}$ 나 $8{ }^{\circ} \mathrm{C}$ 일때의 마취 조건에서 실험직후 전어체 cortisol이 최 대치로, 실험후 6 시간까지 점진적으로 감소한 반면, 전어체 glucose는 실험후 1시간에 최고치를 보이 고 실험후 2시간까지는 감소하였다. 기존의 마취제를 쓰지 않은 본 연구로 인해, 해산송사리의 여타 연구에서 샘플 및 사용자가 보다 더 안전하고 용이한 샘플 취급이 가능할 것으로 사료된다.
\end{abstract}

Key words : Anesthesis, Cortisol, Glucose, Oryzias dancena

\section{I . Introduction}

The use of anesthetics in aquaculture reduces fish energy, allowing for the efficient transportation of fish, ease of handling when measurements are taken, a reduction in the pain and trauma experienced by experimental fish, and reduced handling stress. Bacterial infections in fish are also minimized with the use of anesthetics, especially during surgery, and water temperature-induced anesthesia, which is recognized as stable in fish, can be applied to edible fish without a mandatory period of withdrawal, as is required for other anesthetics (Summerfelt and Smith, 1990).

Cold anesthesia in fish is characterized by an absence of motion, reduced power of exertion, and diminished nervous sensitivity. Before chemical anesthetics were widely used, low-temperature-induced

† Corresponding author: Tel., +82-51-410-4321; E-mail, ispark@kmou.ac.kr 
anesthesia was recommended for minor surgery in fish (Parker, 1939). In human medicine, the low temperatures produced by the vaporization of ethyl chloride, diethyl ether, or solid carbon dioxide have been used to induce local anesthesia in restricted parts of the body because lowering the temperature of an extremity reduces the perception of pain in that area (Considine and Considine, 1984). Cold anesthesia is reversible and leaves no residue in the tissues. No danger is imposed to the user, other than the risk inherent in handling solid carbon dioxide if that material is used.

The immediate response to stress is believed to be adaptive, allowing an organism to respond to a perceived threat, whereas the response to chronic stress is considered maladaptive, with deleterious impacts on growth, reproduction, and the immune response (Schreck et al., 2001). The steroid hormone cortisol is widely accepted as an indicator of stress in fish, generally increasing after exposure to physical stressors (Schreck, 1981). Circulating cortisol levels are typically measured to determine the stress status of an individual fish (Redding and Schreck, 1983). Alternatively, whole-body cortisol levels have been used to assess the stress responses of developing salmonids and flatfish because their blood volumes are insufficient to allow for the measurements of circulating cortisol (Redding and Schreck, 1983). Similarly, whole-body corticosteroids have been measured in smaller adult fish, including the three-spined stickleback, Gasterosteus aculeatus (Pottinger et al., 2002) and the zebrafish, Danio rerio (Pottinger and Calder, 1995). Environmental parameters, including changes in temperature, time of day, and feeding regimen, have been shown to affect the cortisol response and responses to other stressors (Pottinger and Calder, 1995). Temperature changes should be considered in stress studies, particularly when little is known about the stress response of the species examined (Schreck, 1981). Ambient water temperature also dramatically changes the response to stress and the recovery dynamics of fish.

The marine medaka, Oryzias dancena was used in this study. This species, which is nonindigenous to Korea, is a bony fish with a strong tolerance for salinity, based on its salinity-adaptation mechanisms (Inoue and Takei, 2003). In addition to studies of this euryhaline species under various salinity conditions, extensive ecotoxicogenomic research has been undertaken, which should extend the use of the marine medaka as a laboratory model for examining responses to salinity changes. Its viability under conditions of maximum tolerable salinity has been measured and its ability to adapt to variations in salinity has been assessed, particularly during the incubation period (Cho et al., 2010).

Recently, this species was selected by the Institute of Marine Living Modified Organisms (iMLMO), Korea for a project to evaluate living modified organisms. Consistent with this purpose, detailed information on its biology, especially its early gonadogenesis, sexual differentiation, early ontogenesis, and embryogenesis, has begun to be collected (Song et al., 2009a, 2009b). Nam et al. (2010) studied the tolerance to salinity changes of this species. The marine medaka has an exceptional capacity for hyperosmoregulation and hypo- osmoregulation (Nam et al., 2010). Park et al. (2011) examined the effects of clove oil and lidocaine- $\mathrm{HCl}$ on the marine medaka. The results of that study have contributed to the safe laboratory handling of this fish, which is required for many studies. The research discussed above has demonstrated that the marine medaka has the ideal characteristics of an experimental animal (Song et al., 2009a, 2009b; 
Nam et al., 2010; Park et al., 2011).

The aim of this study was to measure the anesthetic effects of heat and cold and recovery time according to induced changes in temperature and to determine the optimum temperature for inducing heat or cold anesthesia in the marine medaka. Additionally we note the operculum movement number (OMN) after recovery. We also determined the whole-body cortisol and glucose levels of adult marine medaka under physiological stress during heat and cold anesthesia.

\section{Materials and methods}

\section{Experimental fish}

Marine medaka, Oryzias dancena were reared for this study according to the methods of Park et al. (2011). The fish used in the experiments had an average body weight of $354.2 \pm 43.60 \mathrm{mg}$ and an average total length of $36.3 \pm 2.13 \mathrm{~mm}$, and were bred in an aquarium maintained at a temperature of $26 \pm 0.5^{\circ} \mathrm{C}$. For fish breeding purposes, an appropriate hanging aquarium water filter was used. The experiments were performed in the laboratory with a day/night cycle of 12:12 h. Standard food was given twice daily, alternating between a formulated diet of Artemia and food placed on the aquarium floor so that it could be eaten within 2 h. Aquarium fish breeding conditions were maintained at 3 5\% and the $\mathrm{pH}$ was kept constant at $6.5 \sim 7.0$.

\section{Heat anesthesia and cold anesthesia}

The anesthesia induced by temperature change was categorized as heat or cold anesthesia, according to our preliminary results. Experimental measurements were taken at heat-anesthesia water temperatures of $36^{\circ} \mathrm{C}, 38^{\circ} \mathrm{C}, 40^{\circ} \mathrm{C}$, and $42^{\circ} \mathrm{C}$, and cold-anesthesia water temperatures of $4^{\circ} \mathrm{C}, 6^{\circ} \mathrm{C}, 8^{\circ} \mathrm{C}$, and $10^{\circ} \mathrm{C}$. The water temperature in the recovery aquarium was $26 \pm 0.5^{\circ} \mathrm{C}$ for both the heat-anesthesia and cold-anesthesia experiments. Twenty specimens per group were used in all experiments. The decision-based table describing the anesthetic effects (Table 1) was modified from data reported by Summerfelt and Smith (1990). Anesthesia time was measured as the time from when the fish were placed in the water at the anesthetic temperature to the time that a state of stage A6 was reached (Table 1), when the fish were perfectly sedated, with minimum opercular movement. The recovery time was determined as the time from when the fish were placed in the recovery tank to the time at which state stage R6 was reached (Table 1), in which normal swimming and responsiveness to visual stimuli were observed.

\section{Measuring operculum movement number}

The OMN was measured before anesthesia and after recovery in experimental and control groups. For each of the experimental and control groups, three individuals were sampled randomly. The OMN was measured five times per sample fish. Before starting the anesthesia, we measured the OMN in all experimental groups and the control group, in which fish remained in a stable state. After the anesthesia, we measured the OMN in all groups at times $0,1,2,6,12,24$, and $48 \mathrm{~h}$. For this purpose, "after the anesthesia" means the time at which the experimental fish recovered in the $26 \pm 0.5^{\circ} \mathrm{C}$ recovery tank.

\section{Whole-body cortisol and glucose responses to heat and cold anesthesia}


$\langle$ Table 1> Stages of anesthesia and recovery in the clove oil efficacy test performed in the marine medaka, Oryzias dancena (modified from stage 1 to stage 22 of Summerfelt and Smith, 1990)

\begin{tabular}{ll}
\hline Stage & \multicolumn{1}{c}{ Characteristic behavior } \\
\hline \hline A1 & Normal swimming; operculum movement and normal general movement \\
A2 & Swimming speed slowed; rolling from side to side \\
A3 & Partial loss of equilibrium; swimming erratic \\
A4 & Complete loss of equilibrium; swimming perfectly inside out; pectoral fin, pelvic \\
& \multicolumn{1}{c}{ fin and dorsal fin movement stop } \\
A5 & Little sedation; anal fin and tail fin movement stop \\
A6 & Perfect sedation; only operculum movement \\
A7 & Operculum movement ceased \\
& \multicolumn{2}{c}{ Recovery } \\
R1 & Resume operculum movement \\
R2 & Preferential movement of pectoral fin and tail fin \\
R3 & Dorsal fin, pelvic fin and anal fin movement \\
R4 & Swimming perfectly inside out \\
R5 & Swimming erratic; redress the balance \\
R6 & Normal swimming; responsiveness to visual stimuli
\end{tabular}

We conducted this experiment to observe the effects of stress on the whole-body cortisol and glucose levels of fish under heat and cold anesthesia. To conduct this experiment, we anesthetized the fish at temperatures of $38^{\circ} \mathrm{C}$ and $8^{\circ} \mathrm{C}$, respectively, and the stress responses of the experimental fish were measured at $0,1,2,6,12$, 24, 48, and 72 h. Control fish were not anesthetized, but their cortisol levels were measured. For these measurements, 20 fish were used in each experimental group, and no distinction was made between male and female fish. We measured the whole-body cortisol and glucose levels of the control fish before the experiment. Individual fish were blotted onto paper towels to remove excess water, immediately frozen in liquid nitrogen for $10 \sim 30 \mathrm{~s}$, and placed in individual $5.0-\mathrm{mL}$ plastic screwcap centrifuge tubes. The samples were stored at $-80^{\circ} \mathrm{C}$ until we extracted the cortisol.

\section{Whole-body cortisol and glucose extraction}

The term "whole-body cortisol" is used to describe the portion of corticosteroid extracted and measured with a cortisol-specific radioimmunoassay (RIA). However, the cortisol antibody may recognize other cortisol metabolites in the whole-body fraction that have not yet been identified (Pottinger et al., 1992). Nevertheless, based on previous studies, we feel confident that the majority of the corticosteroid recognized by the assay was cortisol. Therefore, we have chosen the term "whole-body cortisol" as the descriptor (Feist and Schreck, 2002). Whole-body cortisol was extracted using a modification of the method used for the eggs and embryos of the chinook salmon, Oncorhynchus tshawytscha (Feist and Schreck, 2002). Individual whole, frozen marine medaka were thawed, individually weighed, and placed in a 
glass test tube $(15 \times 85 \mathrm{~mm})$. Each fish was homogenized in deionized water $(0.5 \mathrm{~mL})$ for 45 75 s using a Tissue-Tearor Homogenizer (model 985370-04; BioSpec Products, Inc., Bartlesville, OK, USA). The homogenate on the Tissue Tearor $\mathrm{J}$ probe was rinsed into the sample tube with an additional $0.5 \mathrm{~mL}$ of deionized water.

The homogenized samples were vortexed briefly and placed on ice. The probe was cleaned between samples with distilled water followed by $100 \%$ ethanol, and was then rinsed again with distilled water. The homogenized contents of the glass test tube were transferred to a larger test tube $(16 \times$ $125 \mathrm{~mm})$ to facilitate extraction. The original tube was rinsed with diethyl ether (0848-10; Mallinckrodt Baker, Inc., Paris, KY, USA), which was transferred to the larger tube for subsequent extraction. Each sample was extracted twice with eight volumes $(8 \mathrm{~mL})$ of diethyl ether. For each extraction, the tube was vigorously vortexed with ether for $30 \mathrm{~s}$ and briefly centrifuged $(400 \times \mathrm{g}$ for 2 3 $\mathrm{min}$ ) to separate the aqueous and ether layers. The bottom layer (aqueous homogenate) was frozen in liquid nitrogen for $20 \mathrm{~s}$ and the top ether layer was poured into a new test tube $(16 \times 100 \mathrm{~mm})$ and dried in a Speed-Vac centrifuge (SVC100H; Savant Instruments, Inc., Holbrook, NY, USA). The extraction efficiency was determined for each extraction by adding tritiated cortisol (hydrocortisone, [1, 2, 6, 7- $\left.{ }^{3} \mathrm{H}\right]$-cortisol; \#NET-396; Dupont NEN Research Products, Boston, MA, USA) to the homogenized samples $(\mathrm{N}=20)$ and extracting the samples with the method described above. All sample cortisol levels were corrected for extraction efficiency.

Following the second extraction, the samples were dried in a fume hood overnight, reconstituted with $1 \mathrm{~mL}$ of phosphate-buffered saline containing
1\% gelatin (Sigma, St. Louis, MO, USA), vortexed for $30 \mathrm{~s}$, and stored at $4^{\circ} \mathrm{C}$. The whole-body glucose level was analyzed according to the methodology of Raabo and Terkildsen (1960), with Kit 510 (Sigma), in which the production of $\mathrm{H}_{2} \mathrm{O}_{2}$ by glucose oxidase in the presence of o-dianisidine was evaluated as the increase in absorbance at 450 $\mathrm{nm}$. The experiment was performed twice, and the results are reported as the means \pm standard deviations $(\mathrm{N}=20)$, unless otherwise stated.

\section{Statistical analysis}

One-way analysis of variance (ANOVA) was used to test the significance $(\mathrm{P}<0.05)$ of differences in the OMN between the heat- and cold-anesthesia groups. Differences in cortisol and glucose among the heat, cold, and control groups was analyzed with ANOVA using the SPSS ver. 9.0 statistical package (SPSS Inc., Chicago, IL, USA), and multiple comparisons were made with Duncan's multiple range test. For statistical tests, we conducted the experiments in triplicate.

\section{Results}

No morbidity or mortality was observed in the fish during this anesthesia experiment. The anesthetic effects of heat $\left(36^{\circ} \mathrm{C}, 38^{\circ} \mathrm{C}, 40^{\circ} \mathrm{C}\right.$, and $\left.42^{\circ} \mathrm{C}\right)$ and cold $\left(4^{\circ} \mathrm{C}, 6^{\circ} \mathrm{C}, 8^{\circ} \mathrm{C}\right.$, and $\left.10^{\circ} \mathrm{C}\right)$ on the marine medaka, Oryzias dancena are shown in Table 2. The period of anesthesia and the recovery time in the heat-anesthesia groups were in the ranges of 6.9 35.2 $\mathrm{s}$ and 37.2 73.1 $\mathrm{s}$, respectively $(\mathrm{P}<0.05)$. The period of anesthesia and the recovery time in the cold-anesthesia group were in the ranges of 5.7 23.2 $\mathrm{s}$ and 56.4 85.4 s, respectively $(\mathrm{P}<0.05)$. 
$\langle$ Table 2> Duration of anesthesia and recovery time for marine medaka, Oryzias dancena, anesthetized with different levels of heat $\left(36,38,40\right.$ and $\left.42^{\circ} \mathrm{C}\right)$ or cold $\left(4,6,8\right.$ and $\left.10^{\circ} \mathrm{C}\right)$

\begin{tabular}{|c|c|c|}
\hline \multirow{2}{*}{$\begin{array}{c}\text { Temperature } \\
\left({ }^{\circ} \mathrm{C}\right)\end{array}$} & \multicolumn{2}{|c|}{ Time $(\mathrm{sec})^{*}$} \\
\hline & Anesthesia & Recovery \\
\hline & \multicolumn{2}{|c|}{ Heat } \\
\hline 42 & $6.9 \pm 1.31^{\mathrm{d}}$ & $73.1 \pm 6.28^{\mathrm{c}}$ \\
\hline 40 & $8.7 \pm 1.01^{\mathrm{c}}$ & $62.8 \pm 3.53^{\mathrm{b}}$ \\
\hline 38 & $28.1 \pm 1.27^{\mathrm{b}}$ & $38.4 \pm 1.53^{\mathrm{a}}$ \\
\hline \multirow[t]{2}{*}{36} & $35.2 \pm 1.82^{\mathrm{a}}$ & $37.2 \pm 0.86^{\mathrm{a}}$ \\
\hline & \multicolumn{2}{|c|}{ Cold } \\
\hline 10 & $23.2 \pm 1.11^{\mathrm{d}}$ & $56.4 \pm 0.78^{\mathrm{d}}$ \\
\hline 8 & $11.6 \pm 1.53^{\mathrm{c}}$ & $61.7 \pm 1.72^{\mathrm{c}}$ \\
\hline 6 & $7.3 \pm 1.20^{\mathrm{b}}$ & $70.7 \pm 2.03^{b}$ \\
\hline 4 & $5.7 \pm 1.14^{\mathrm{a}}$ & $85.4 \pm 1.37^{\mathrm{a}}$ \\
\hline $\begin{array}{l}{ }^{*} \text { Each valu } \\
(N=20) \quad \mathrm{f} \\
\text { occasions. } \\
\text { common } \\
\text { different }(\end{array}$ & $\begin{array}{l}\text { are the } \mathrm{m} \\
\text { experiments } \\
\text { lues in the } \\
\text { perscript le } \\
.05) \text {. }\end{array}$ & $\begin{array}{l}\text { deviations } \\
\text { on three } \\
\text { not sharing } \\
\text { significantly }\end{array}$ \\
\hline
\end{tabular}

As shown in Table 2, among the heat-anesthesia groups, the anesthesia and recovery times under the $42^{\circ} \mathrm{C}$ treatment were $6.9 \pm 1.31$ and $73.1 \pm 6.28 \mathrm{~s}$, respectively, while those under the $36^{\circ} \mathrm{C}$ treatment were $35.2 \pm 1.82$ and $37.2 \pm 0.86 \mathrm{~s}$, respectively. This shows that in fish anesthetized by heat, the anesthesia time decreased but the recovery time increased when the temperature was increased $(\mathrm{P}<0.05)$. In the cold-treatment group, the anesthesia and recovery times under the $10^{\circ} \mathrm{C}$ treatment were $23.2 \pm 1.11$ and $56.4 \pm 0.78 \mathrm{~s}$, respectively, while those under the $4^{\circ} \mathrm{C}$ treatment were $5.7 \pm 1.14$ and $85.4 \pm 1.37 \mathrm{~s}$, respectively. That is, the period of anesthesia decreased but the recovery time increased as the temperature decreased $(\mathrm{P}<0.05)$. Thus, the anesthetic effects of temperature on the marine medaka increased with increases in temperature in the heat-anesthesia groups and increased when the temperature was decreased in the cold-anesthesia groups. The recovery times from heat or cold anesthesia decreased when fish were treated at high temperature or low temperature, respectively. All experimental animals in each anesthetic treatment group survived the experiment.

Figures 1 and 2 show the OMNs when experimental fish were anesthetized under high temperatures $\left(36^{\circ} \mathrm{C}, 38^{\circ} \mathrm{C}, 40^{\circ} \mathrm{C}\right.$, and $\left.42^{\circ} \mathrm{C}\right)$ or low temperatures $\left(4^{\circ} \mathrm{C}, 6^{\circ} \mathrm{C}, 8^{\circ} \mathrm{C}\right.$, and $\left.10^{\circ} \mathrm{C}\right)$. In the heat-anesthesia groups, when the anesthesia temperature increased, the $\mathrm{OMN}$ also increased. At $42^{\circ} \mathrm{C}$, the $\mathrm{OMN}$ was significantly higher than those at $36^{\circ} \mathrm{C}, 38^{\circ} \mathrm{C}$, and $40^{\circ} \mathrm{C}$ until $6 \mathrm{~h}$ had elapsed $(\mathrm{P}<0.05)$. As shown in Fig. 1, during the experiment, the $\mathrm{OMN}$ of the $42^{\circ} \mathrm{C}$ group decreased gradually from $0 \mathrm{~h}$ to $24 \mathrm{~h}$. By $24 \mathrm{~h}$, the OMN of the $42^{\circ} \mathrm{C}$ group was similar to that of the control. At $40^{\circ} \mathrm{C}$, the $\mathrm{OMN}$ was significantly higher than at $36^{\circ} \mathrm{C}$ and $38^{\circ} \mathrm{C}$ until $6 \mathrm{~h}$ had elapsed $(\mathrm{P}<0.05)$ and during the experiment, the $\mathrm{OMN}$ of the $40^{\circ} \mathrm{C}$ group decreased gradually from $0 \mathrm{~h}$ to $48 \mathrm{~h}$. By $24 \mathrm{~h}$, the OMN was similar to that of the control group. From $0 \mathrm{~h}$ to $6 \mathrm{~h}$, the $42^{\circ} \mathrm{C}$ group showed the highest OMN among the heat-anesthesia groups, followed by the $40^{\circ} \mathrm{C}$ group.

At $0 \mathrm{~h}$, the $\mathrm{OMN}$ of the $42^{\circ} \mathrm{C}$ group was $320.3 \pm 5.7 / \mathrm{min}$, that of the $40^{\circ} \mathrm{C}$ group was $305.7 \pm 8.2 / \mathrm{min}$, those of the $38^{\circ} \mathrm{C}$ and $36^{\circ} \mathrm{C}$ groups were $297.1 \pm 8.1 / \mathrm{min}$ and $295.8 \pm 9.8 / \mathrm{min}$, respectively, and the OMNs of all groups were higher than that of the control group $(\mathrm{P}<0.05)$. At $1 \mathrm{~h}$, the $\mathrm{OMN}$ of the $42^{\circ} \mathrm{C}$ group was $311.1 \pm 8.2 / \mathrm{min}$. The OMN of the $40^{\circ} \mathrm{C}$ group was $298.2 \pm 7.9 / \mathrm{min}$, and those of the $38^{\circ} \mathrm{C}$ and $36^{\circ} \mathrm{C}$ groups were $288.9 \pm 5.1 / \mathrm{min}$ and $285.2 \pm 6.7 / \mathrm{min}$, respectively; these had decreased significantly from the results at $0 \mathrm{~h}(\mathrm{P}<0.05)$. At 6 


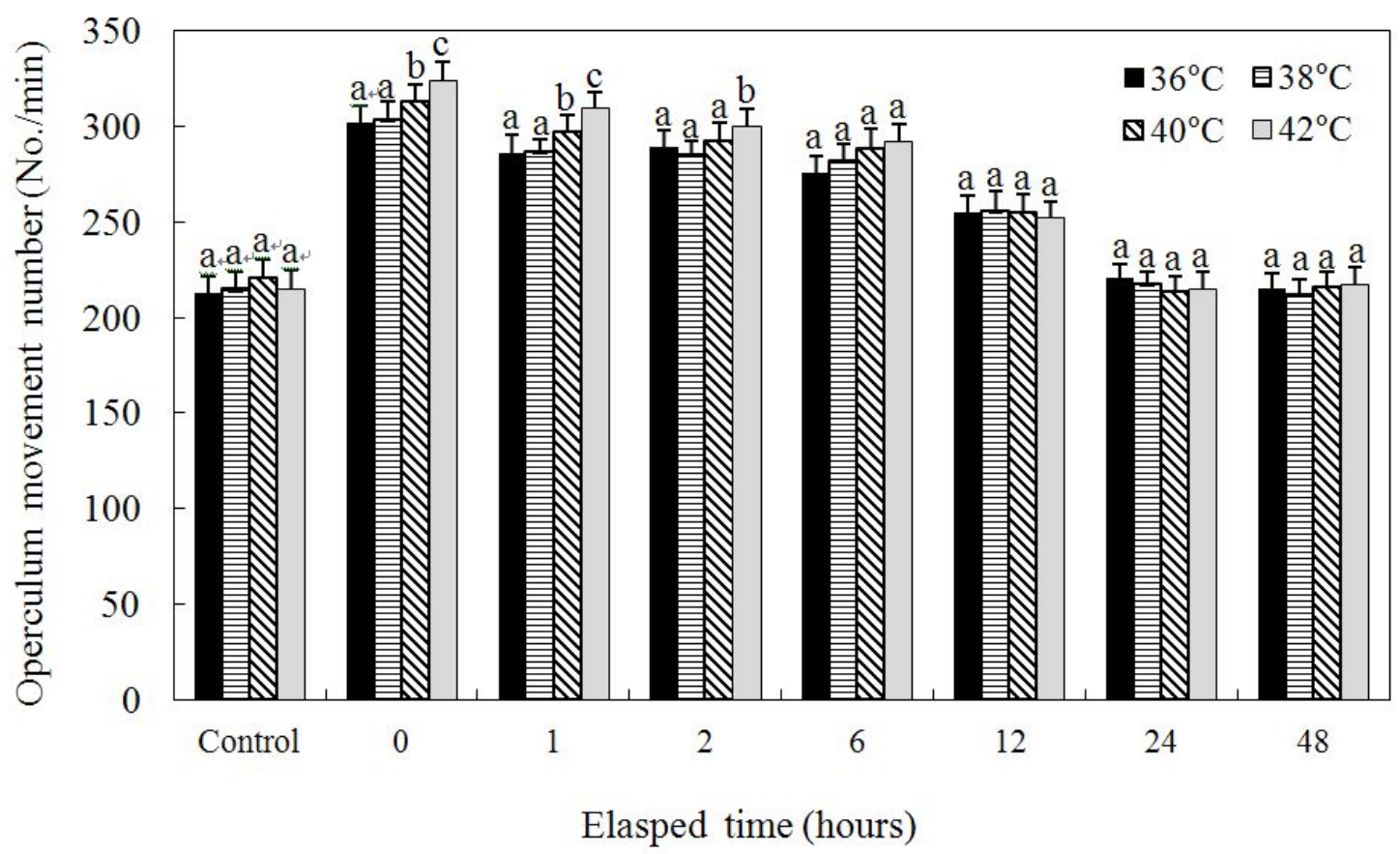

[Fig. 1] Operculum movement number (OMN) of marine medaka, Oryzias dancena which was heat-anesthesia at $36,38,40$ and $42^{\circ} \mathrm{C}$. After the recovery, OMN were measured by time $(0,1,2,6,12,24$ and $48 \mathrm{~h})$. Values are the means \pm standard deviations $(\mathrm{N}=20)$ of experiments performed on three occasions. Different letters on the bars indicate a statistically significant difference in the treatment groups (Duncan's multiple range test, $P<0.05$ ).

and $12 \mathrm{~h}$, all groups showed decreasing tendencies with time. At $24 \mathrm{~h}$, the $\mathrm{OMN}$ of the $42^{\circ} \mathrm{C}$ group was $211.3 \pm 5.4 / \mathrm{min}$, that of the $40^{\circ} \mathrm{C}$ group was $208.1 \pm 5.7 / \mathrm{min}$, and those of the $38^{\circ} \mathrm{C}$ and $36^{\circ} \mathrm{C}$ groups were $215.7 \pm 4.9 / \mathrm{min}$ and $218.2 \pm 5.3 / \mathrm{min}$, respectively $(\mathrm{P}<0.05)$, with no significant difference from the control group $(\mathrm{P}<0.05)$. Immediately after recovery, the $\mathrm{OMN}$ in the $42^{\circ} \mathrm{C}$ group was the highest among the heat-anesthetized groups. The experimental groups showed significantly elevated OMNs over that of the control group. Also, in all experimental groups, the OMN decreased with time. After $24 \mathrm{~h}$, the OMN values of all experimental groups were similar to that of the control group $(\mathrm{P}<0.05)$.
Figure 2 shows the OMN when experimental fish were anesthetized in cold temperatures of $4^{\circ} \mathrm{C}$, $6^{\circ} \mathrm{C}, 8^{\circ} \mathrm{C}$, and $10^{\circ} \mathrm{C}$. In the cold-anesthesia groups, when the anesthesia temperature decreased, the OMN increased. In the $4^{\circ} \mathrm{C}$ group, the $\mathrm{OMN}$ was significantly higher than those in the $6^{\circ} \mathrm{C}, 8^{\circ} \mathrm{C}$, and $10^{\circ} \mathrm{C}$ groups until $12 \mathrm{~h}$ had elapsed $(\mathrm{P}<0.05)$. During the experiment, the $\mathrm{OMN}$ in the $4^{\circ} \mathrm{C}$ group decreased gradually from 0 to $24 \mathrm{~h}$ until, at $24 \mathrm{~h}$, the $\mathrm{OMN}$ in the $4^{\circ} \mathrm{C}$ group was similar to that of the control. In the $6^{\circ} \mathrm{C}$ group, the $\mathrm{OMN}$ was significantly higher than those in the $8^{\circ} \mathrm{C}$ and $10^{\circ} \mathrm{C}$ groups until $2 \mathrm{~h}$ had elapsed $(\mathrm{P}<0.05)$. During the experiment, the $\mathrm{OMN}$ of the $6^{\circ} \mathrm{C}$ group decreased gradually from 0 to $24 \mathrm{~h}$ until, at $24 \mathrm{~h}$, the $\mathrm{OMN}$ 


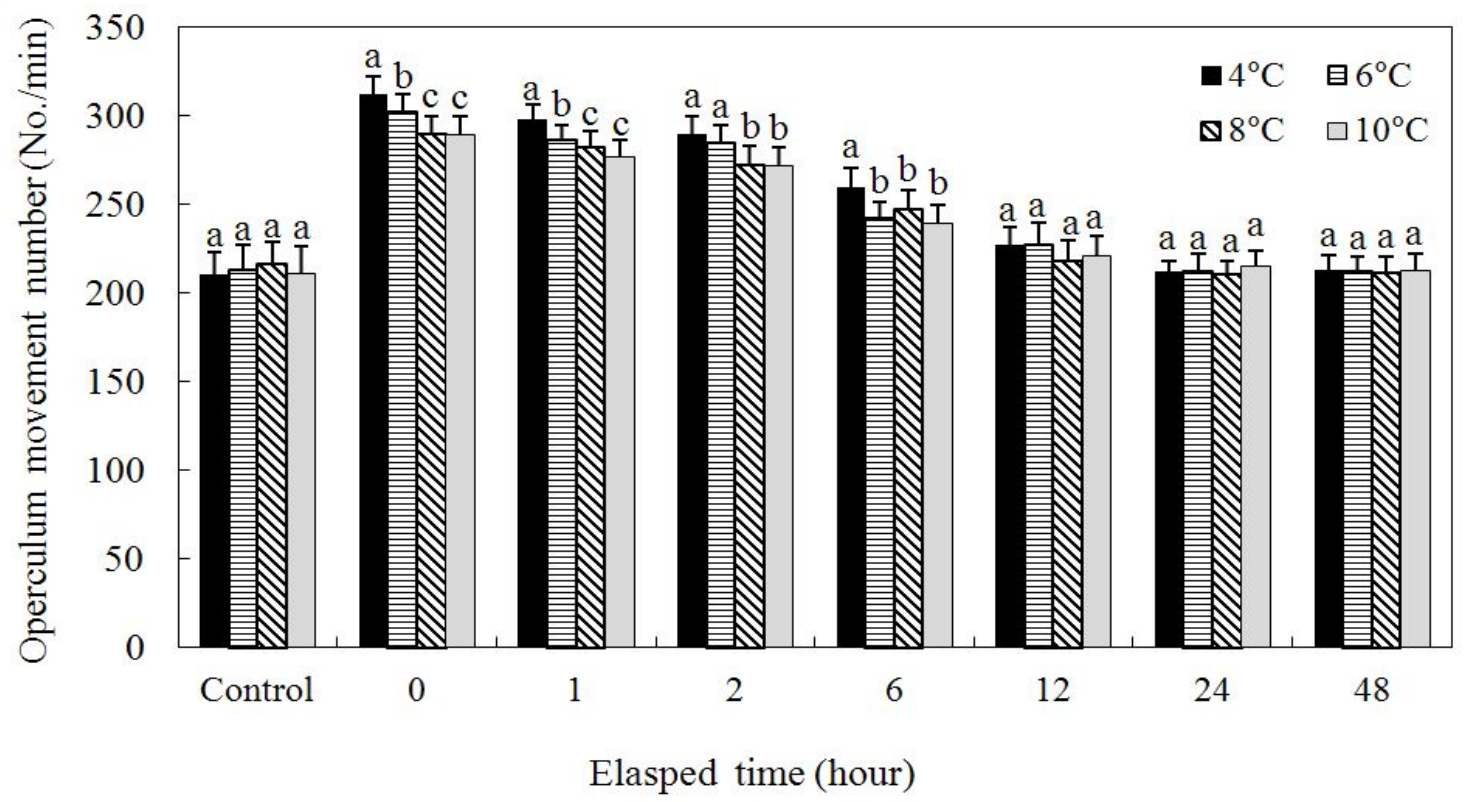

[Fig. 2] Operculum movement number (OMN) of marine medaka, Oryzias dancena which was cold anesthesia at $4,6,8$ and $10^{\circ} \mathrm{C}$. After the recovery, OMN were measured by time $(0,1,2,6$, $12,24$ and $48 \mathrm{~h})$. Values are the means \pm standard deviations $(\mathrm{N}=20)$ of experiments performed on three occasions. Different letters on the bars indicate a statistically significant difference in the treatment groups (Duncan's multiple range test, $P<0.05$ ).

was similar to that of the control group. From 0 to $12 \mathrm{~h}$, the $4^{\circ} \mathrm{C}$ group showed the highest OMN among the cold-anesthesia groups, followed by the $6^{\circ} \mathrm{C}$ group.

At $0 \mathrm{~h}$, the $\mathrm{OMN}$ of the $4^{\circ} \mathrm{C}$ group was $319.4 \pm 8.1 / \mathrm{min}$, that of the $6^{\circ} \mathrm{C}$ group was $308.2 \pm 7.9 / \mathrm{min}$, and those of the $8^{\circ} \mathrm{C}$ and $10^{\circ} \mathrm{C}$ groups were $298.2 \pm 6.9 / \mathrm{min}$ and $296.4 \pm 8.7 / \mathrm{min}$, respectively $(\mathrm{P}<0.05)$. At this point, the $\mathrm{OMN}$ among all experimental groups had increased over that of the control group $(\mathrm{P}<0.05)$. No significant difference was observed in the OMN between the $6^{\circ} \mathrm{C}$ and $8^{\circ} \mathrm{C}$ groups at $0 \mathrm{~h}(\mathrm{P}<0.05)$. At $1 \mathrm{~h}$, the OMN of all groups had decreased significantly compared to those recorded at $0 \mathrm{~h} \quad(\mathrm{P}<0.05)$. At this point, the $\mathrm{OMN}$ of the $4^{\circ} \mathrm{C}$ group was $303.8 \pm 6.7 / \mathrm{min}$, that of the $6^{\circ} \mathrm{C}$ group was
$294.3 \pm 6.3 / \mathrm{min}$, and those of the $8^{\circ} \mathrm{C}$ and $10^{\circ} \mathrm{C}$ groups were $285.9 \pm 4.2 / \mathrm{min}$ and $283.7 \pm 5.5 / \mathrm{min}$, respectively $(\mathrm{P}<0.05)$. At $2 \mathrm{~h}$, the $\mathrm{OMN}$ of the $4^{\circ} \mathrm{C}$ group was $295.7 \pm 6.9 / \mathrm{min}$, that of the $6^{\circ} \mathrm{C}$ group was $289.3 \pm 5.8 / \mathrm{min}$, and those of the $8^{\circ} \mathrm{C}$ and $10^{\circ} \mathrm{C}$ groups were $279.5 \pm 4.9 / \mathrm{min}$ and $277.1 \pm 6.1 / \mathrm{min}$, respectively $(\mathrm{P}<0.05)$. From $6 \mathrm{~h}$ to $12 \mathrm{~h}$, the $\mathrm{OMN}$ decreased greatly, with that of the $4^{\circ} \mathrm{C}$ group decreasing from $268.3 \pm 6.1 / \mathrm{min}$ at $6 \mathrm{~h}$ to $224.6 \pm 6.9 / \mathrm{min}$ at $12 \mathrm{~h}$. Thus, the OMN showed a tendency to decrease with time. At $24 \mathrm{~h}$, the $\mathrm{OMN}$ of the $4^{\circ} \mathrm{C}$ group was $210.5 \pm 6.5 / \mathrm{min}$, that of the $6^{\circ} \mathrm{C}$ group was $21.1 \pm 4.0 / \mathrm{min}$, and those of the $8^{\circ} \mathrm{C}$ and $10^{\circ} \mathrm{C}$ groups were $211.7 \pm 3.7 / \mathrm{min}$ and $215.8 \pm 5.1 / \mathrm{min}$, respectively $(\mathrm{P}<0.05)$. These values showed no significant difference from that of the control group $(\mathrm{P}<0.05)$. 


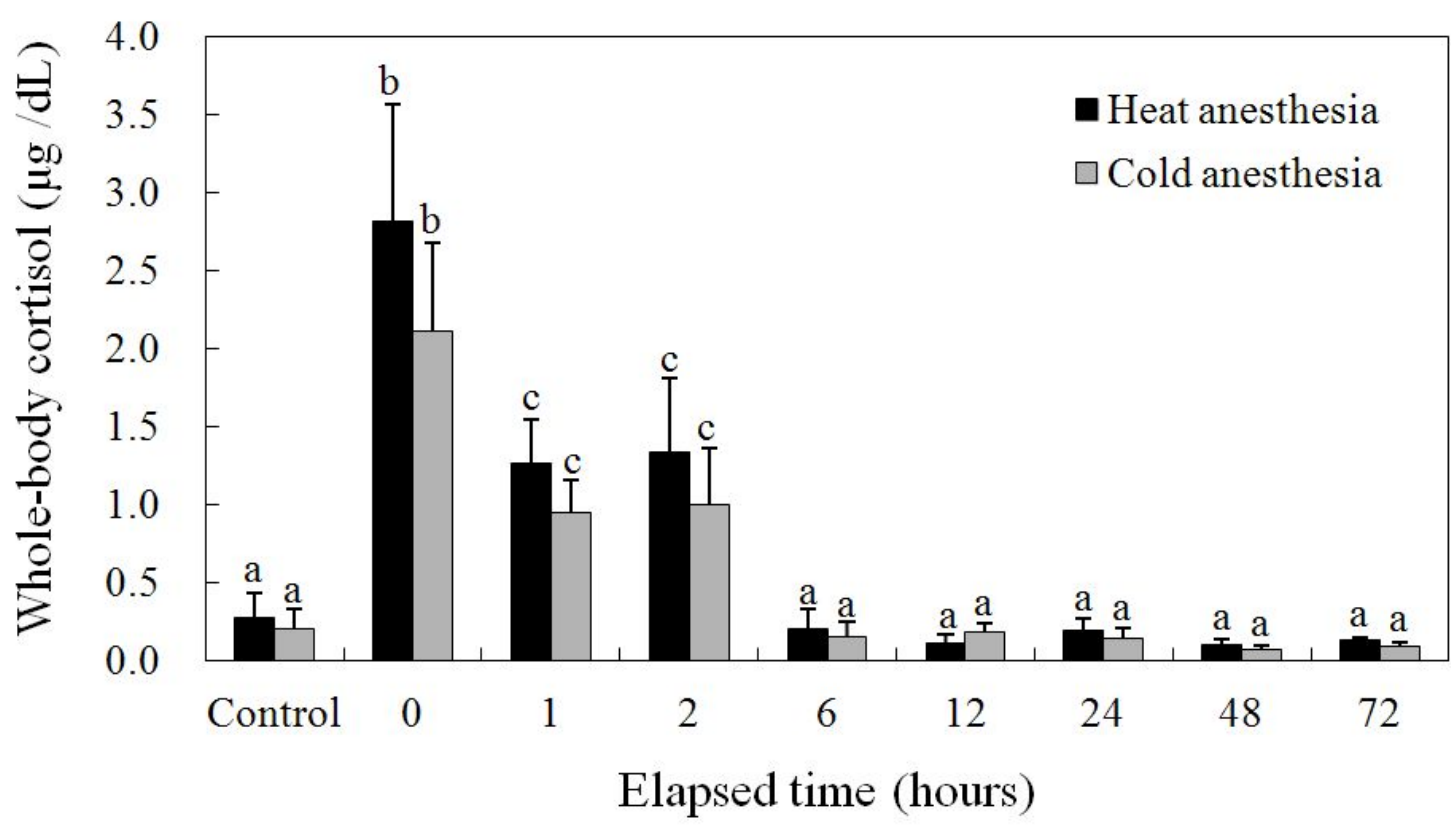

[Fig. 3] Physiological measurements (means \pm standard deviations) of whole-body cortisol after recovery when the marine medaka, Oryzias dancena was anesthetized at 38 and $8^{\circ} \mathrm{C}$. Values are the means \pm standard deviations $(\mathrm{N}=20)$ for experiments performed on three occasions. Different letters on the bars indicate a statistically significant difference between the experiment and the control groups at a single sampling time (Duncan's multiple range test, $P<0.05$ ).

Figure 3 shows the rate of change in whole-body cortisol in the experimental fish after their recovery from heat and cold anesthesia at $38^{\circ} \mathrm{C}$ and $8^{\circ} \mathrm{C}$, respectively. Cortisol decreased with time under both high- and low-temperature anesthesia. First, under heat anesthesia, the whole-body cortisol was $2.81 \mu \mathrm{g} / \mathrm{dL}$ at $0 \mathrm{~h}, 1.33$ $\mu \mathrm{g} / \mathrm{dL}$ at $1 \mathrm{~h}$, and $0.21 \mu \mathrm{g} / \mathrm{dL}$ at $2 \mathrm{~h}$. Also, from 0 to $2 \mathrm{~h}$, the cortisol in the $38^{\circ} \mathrm{C}$ group was significantly higher than that in the control group. At $6 \mathrm{~h}$, the cortisol level in the $38^{\circ} \mathrm{C}$ group was similar to that of the control group. Under low-temperature anesthesia, the whole-body cortisol was $2.1 \mu \mathrm{g} / \mathrm{dL}$ at $0 \mathrm{~h}, 1.0 \mu \mathrm{g} / \mathrm{dL}$ at $1 \mathrm{~h}$, and 0.2 $\mu \mathrm{g} / \mathrm{dL}$ at $2 \mathrm{~h}$. From 0 to $2 \mathrm{~h}$, the cortisol level in the $8^{\circ} \mathrm{C}$ group was significantly higher than that of the control. At $6 \mathrm{~h}$, the cortisol level in the $8^{\circ} \mathrm{C}$ group was similar to that of the control group. These results show that cortisol decreased with time and that the tendency of change in the whole-body cortisol was similar under both heat and cold anesthesia.

Figure 4 shows the rate of change in whole-body glucose in the experimental fish after their recovery from heat and cold anesthesia at $38^{\circ} \mathrm{C}$ and $8^{\circ} \mathrm{C}$, respectively. Under $38^{\circ} \mathrm{C}$ heat anesthesia, the whole-body glucose was $2.6 \mathrm{mg} / \mathrm{dL}$ at $1 \mathrm{~h}$ and then decreased sharply. After $2 \mathrm{~h}$, the whole-body glucose of the heat-anesthesia group was similar to that of the control group. In cold anesthesia at $8^{\circ} \mathrm{C}$, the whole-body glucose was 1.1 $\mathrm{mg} / \mathrm{dL}$ at $1 \mathrm{~h}$ and then decreased sharply by $2 \mathrm{~h}$. At $2 \mathrm{~h}$, the whole-body glucose of the cold-anesthesia group was similar to that of the 


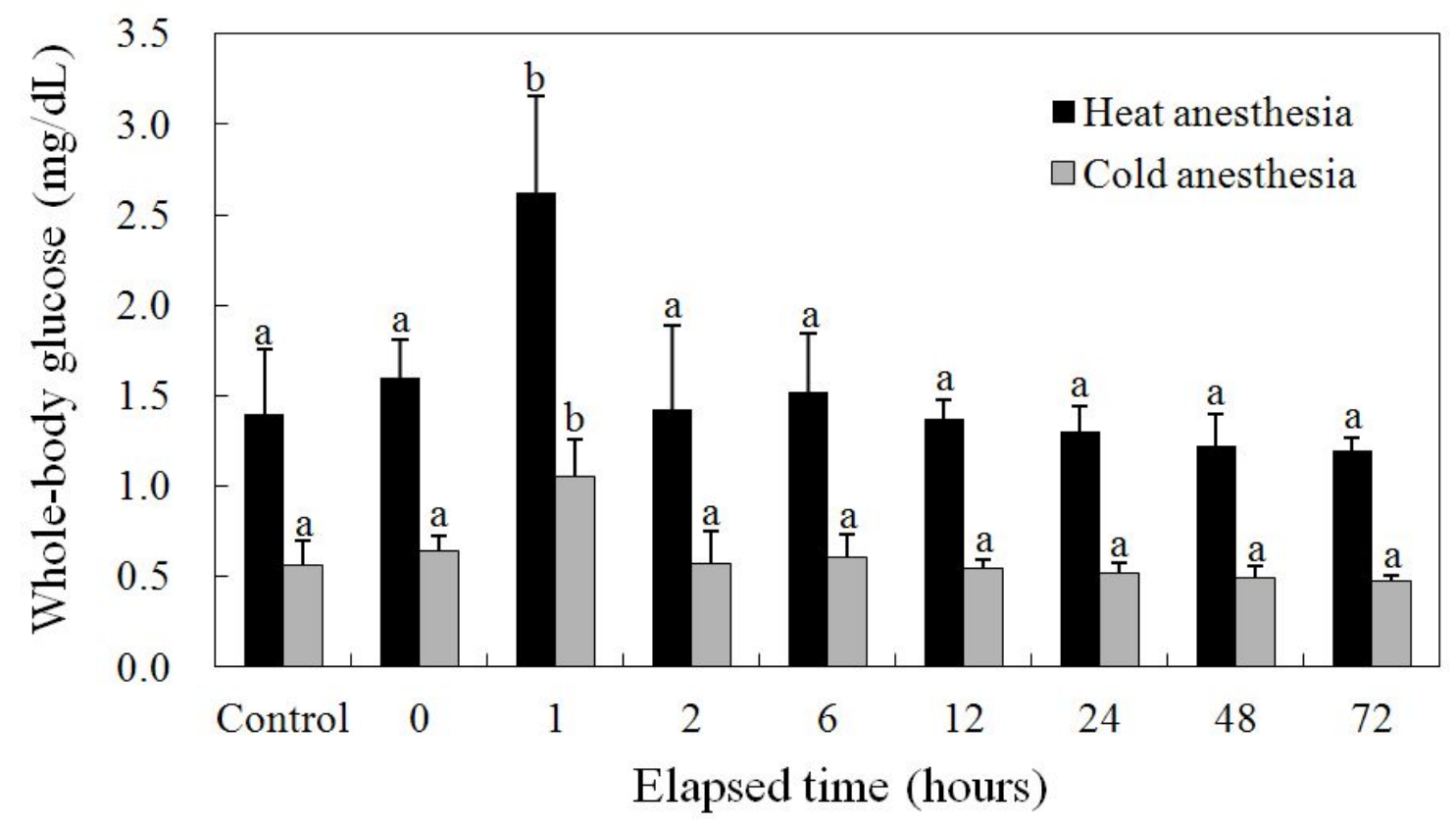

[Fig. 4] Physiological measurements (means \pm Standard deviations) of whole-body glucose after the recovery when the marine medaka, Oryzias dancena was anesthetized at 38 and $8^{\circ} \mathrm{C}$. Values are the means \pm standard deviations $(\mathrm{N}=20)$ of experiments performed on three occasions. Different letters on the bars indicate a statistically significant difference between the treatment and control groups at a single sampling time (Duncan's multiple range test, $P<0.05$ ).

control group. Thus, the tendency for change in whole-body glucose was highest at $1 \mathrm{~h}$, and showed similar tendencies when experimental fish were exposed to either heat $\left(38^{\circ} \mathrm{C}\right)$ or cold $\left(8^{\circ} \mathrm{C}\right)$ anesthesia.

\section{Discussion}

Throughout this study, the effects of heat- and cold-induced anesthesia on the marine medaka, Oryzias dancena were investigated at different temperatures. Low temperature may be used as an anesthetic alone or in combination with an anesthetic drug; both approaches have been used in fisheries work (Meehan and Revet, 1962; Chung, 1980; Williamson and Roberts, 1981). Williamson and Roberts (1981) reported that for minor diagnostic procedures, it was sufficient to immerse fish in crushed ice for $10-15 \mathrm{~min}$. Tilapia, Oreochromis niloticus and Cyprinodontids were anesthetized by being cooled from acclimation temperatures of $24-33^{\circ} \mathrm{C}$ to temperatures of $8.5^{-}$ $11.5^{\circ} \mathrm{C}$ (tilapia) or $3.4-6.8^{\circ} \mathrm{C}$ (Cyprinodontids; Chung, 1980). The fish recovered in $1-2 \mathrm{~min}$, with $100 \%$ survival. However, fish adapted to $10^{\circ} \mathrm{C}$ were not entirely inactive at $1^{\circ} \mathrm{C}$. Meehan and Revet (1962) had equally good success in anesthetizing the catfish, Silurus asotus, the goldfish, Carassius auratus, and the marine blenny, Pholis nebulosa by cooling them from $23-25^{\circ} \mathrm{C}$ to $1^{\circ} \mathrm{C}$ in $2-10 \mathrm{~min}$. All the fish recovered with no apparent ill effects. Previously, Lee et al. (2008) reported that the OMN of rainbow trout, Oncorhynchus mykiss increased greatly when the water temperature 
changed rapidly. Rainbow trout were adapted at $10^{\circ} \mathrm{C}$ for a week, and their $\mathrm{OMN}$ was $114 / \mathrm{min}$, but when the temperature was raised from $10^{\circ} \mathrm{C}$ to $20^{\circ} \mathrm{C}$, the $\mathrm{OMN}$ increased significantly to $140 / \mathrm{min}$ $(\mathrm{P}<0.05)$. This was similar to our results, because in marine medaka adapted to $26^{\circ} \mathrm{C}$ for a week, the OMN was $210.7 \pm 3.2 / \mathrm{min} \quad(\mathrm{P}<0.05)$, but when the fish were anesthetized at $42^{\circ} \mathrm{C}$, the $\mathrm{OMN}$ increased to $320.3 \pm 5.7 / \mathrm{min}(\mathrm{P}<0.05)$. Additionally, all fish in both experiments recovered with no apparent ill effects.

In the present results, cold-anesthesia groups were treated at $4-10^{\circ} \mathrm{C}$ and showed anesthesia times of 5.7-23.2 $\mathrm{s}$ and recovery times of 56.4$85.4 \mathrm{~s}$, with all individuals surviving. The heat-anesthesia groups were treated at $36-42^{\circ} \mathrm{C}$ and showed anesthesia times of 6.9-35.2 $\mathrm{s}$ and recovery times of 38.4-73.1 s, with all individuals surviving. Gilderhus and Marking (1987) proposed that the optimum conditions for anesthesia include a period of anesthesia of less than $3 \mathrm{~min}$ and a recovery time of less than $10 \mathrm{~min}$. Therefore, both heat and cold anesthesia are suitable methods of anesthesia for the marine medaka.

Whole-body cortisol and glucose levels are recognized as useful indicators of stress in fish (Schreck, 1981; Park et al., 2008). Plasma cortisol and glucose values in the red drum, Sciaenops ocellatus simultaneously exposed to MS-222 and quinaldine anesthetics were reported to be elevated (Massee et al., 1995). Barton and Iwama (1991) stated that "Usually, phenomenon that plasma cortisol concentration of fishes rises by stress is first order reaction, phenomenon that plasma glucose concentration rises is result of second-order first order reaction by hormone rise reaction by stress." This trend has also been reported in the gray mullet, Mugil cephalus and the kelp grouper,
Epinephelus bruneus (Park et al., 2008).

The report by Barton and Iwama (1991) was similar to our results because we studied the relationship between physiological responses and heat- and cold-induced anesthesia. Under both heat and cold anesthesia, the whole-body cortisol was always elevated at $0 \mathrm{~h}$ and gradually decreased with time at both $38^{\circ} \mathrm{C}$ and $8^{\circ} \mathrm{C}$. In contrast, the whole-body glucose was most elevated at $1 \mathrm{~h}$, and levels decreased thereafter at $38^{\circ} \mathrm{C}$ and $8^{\circ} \mathrm{C}$. Our results show that whole-body cortisol levels increased faster than glucose levels. This result is similar to that of a study carried out by Park et al. (2008). Similarly, whole-body corticosteroids have been measured in smaller adult fish, including the three-spined stickleback, Gasterosteus aculeatus (Pottinger et al., 2002) and the zebrafish (Pottinger and Calder, 1995).

The whole-body cortisol level of anesthetized marine medaka returned most closely to that of the control at $6 \mathrm{~h}$ after recovery, whereas the whole-body glucose level returned most closely to the control level at $2 \mathrm{~h}$ after recovery.

In our experiments, although oxygen consumption was not studied, oxygen consumption and the OMN are changed by temperature, salinity, stress, or various other factors (Brett and Glass, 1973; Barton and Schreck, 1987). From increases in the OMN, it can be inferred that a fish in a suitable physiologically active state is consuming high amounts of oxygen, and that a fish under unfavorable conditions is attempting to overcome a detrimental state. By increasing the OMN, a fish increases its oxygen consumption in the short term (Lee and Hur, 2004; Lee and Kim, 2005). In this study, when fish were anesthetized by heat and cold, the OMN greatly increased because the fish were attempting to overcome unfavorable conditions. 
At $0 \mathrm{~h}$, the whole-body cortisol levels in both heatand cold-anesthesia groups were high compared with those of the control group $(\mathrm{P}<0.05)$. This means that both heat and cold anesthesia affected the stress response. The OMN in the heat- and cold-anesthesia groups showed a similar tendency, with the OMN decreasing over time. The whole-body cortisol and glucose levels also showed tendencies to decrease over time under heat or cold anesthesia. These results are in accord with those of Barton and Iwama (1991).

This study demonstrated that heat- and cold-induced anesthesia can be used effectively to anesthetize the marine medaka. We documented $100 \%$ survival rates and the affected physiological stress responses in whole-body cortisol and glucose under heat- and cold-induced anesthesia. Additionally, we observed the OMN after recovery when experimental fish were anesthetized by heat or cold. Few previous studies have reported the anesthetic effects of temperature changes in this species. Therefore, this study extends previous research and its results should contribute to the safe laboratory handling of marine medaka, which is required for further research. Future studies of the marine medaka should compare the physiological responses induced by clove oil, MS-222, and other fish anesthetics.

\section{Acknowledgment}

This research was supported by a research grant from the National Fisheries Research \& Development Institute, Busan, Korea. We thank H. W. Gil (Division of Marine Environment and Bioscience, Korea Maritime and Ocean University, Busan, Korea) for his assistance with fish care and many other aspects of the study. We also thank the anonymous referees for their constructive comments. We declare that all experiments in this study complied with the current laws of Korea (Ordinance of Agriculture, Food and Fisheries, No. 1, and the Law Pertaining to Experimental Animals, No. 9932).

\section{Reference}

Barton, B. A. and Iwama, G. K.(1991). Physiological changes in fish from stress in aquaculture with emphasis on the response and effects of corticosteroids, Annual Review of Fish Diseases 1, 3 26.

Barton, B. A and Schreck, C. B.(1987). Influence of acclimation temperature on interenal and carbohydrate stress responses in juvenile chinook salmon (Oncorhynchus tshawytscha), Aquaculture 62, 299 310.

Brett, J. R and Glass, N. R.(1973). Oxygen consumption and critical swimming speeds of sockeye salmon (Oncorhynchus nerka) in relation to size and temperature, Journal of the Fisheries Reasearch Board of Canada 30, 379 387.

Cho, Y. S. - Lee, S. Y. - Kim, D. S. and Nam, Y. K.(2010). Tolerance capacity to salinity change in adult and larva of Oryzias dancena, a euryhaline medaka, Korean Journal of Ichthyology 21, 9 16.

Chung, K. S.(1980). Cold anaesthesia of tropical fish, Bulletin of the Japan Society of Scientific Fisheries 46, 391.

Considine, D. M. and Considine, G. D.(1984). Van nostrand reinhold encycloperdia of chemicals on rainbow trout, North American Journal of Fisheries Management 7, 288 292.

Feist, G. and Schreck, C. B.(2002). Ontogeny of the stress response in chinook salmon, Oncorhynchus tshawytscha, Fish Physioloy and Biochemistry 25, 31 40.

Gilderhus, P. A. and Marking, L. L.(1987). Comparative efficacy of quinaldine sulfate: MS-222 mixtures for the anesthetization of freshwater fish, U.S. Fish and Wildlife Service, Investigations in Fish Control, 
59.

Inoue, K. and Takei, Y.(2003). Asian medaka fishes offer new models for studying mechanisms of seawater adaptation, Comparative Biochemistry and Physiology Part B, Biochemistry and Molecular Biology 136, 635 645.

Lee, J. Y. and Hur, J. W.(2004). Effect of vibration stress on the oxygen consumption, ammonia excretion and blood characteristics of the cultured eel, Anguilla japonica, Journal of Aquaculture 17, 262 267, (in Korean with an English abstract).

Lee, J. Y. and Kim, D. B.(2005). The optimum salinity and the effects of the rapid salinity change on oxygen consumption and nitrogen excretion in river puffer, Takifugu obscrus, Journal of Aquaculture 18, 45 51, (in Korean with an English abstract).

Lee, J. Y. · So, S. Y. and Hur, J. W.(2008). Variation of oxygen consumption, operculum movement number and hemoglobin by water temperature change in rainbow trout, Oncorhynchus mykiss, Korean Journal of Ichthyology 20, 239 247, (in Korean with an English abstract).

Massee, K. C. - Rust, M. B. - Hardy, R. W. and Stickney, R. S.(1995). The effectiveness of tricaine, quinaldine sulfate and metomidate as anesthetics for larval fish, Aquaculture 134, 315 359.

Meehan, W. R. and Revet, L. R.(1962). The effect of tricaine methanesulfonate (MS-222) and/or chilled water on oxygen consumption of sockeye salmon fry, Progressive Fish-Culturist 24, 185 187.

Nam, Y. K. - Cho, Y. S. - Lee, S. Y. and Kim, D. S.(2010). Tolerance capacity to salinity changes in adult and larva of Oryzias dancena, a euryhaline medaka, Korean Journal of Ichthyology 22, 9 16, (in Korean with an English abstract).

Park, I. -S. • Park, S. J. • Gil, H. W. • Nam, Y. K. and Kim, D. S.(2011). Anesthetic effects of clove oil and lidocaine- $\mathrm{HCl}$ on marine medaka, Oryzias dancena, Lab Animal 40, 45 51.

Park, M. O. · Hur, W. J. • Im, S. -Y. • Seol, D. -W. - Lee, J. H. and Park, I. -S.(2008). Anesthetic efficacy and physiological responses to clove oil-anaestheized kelp grouper, Epinephelus bruneus, Aquaculture Research 39, 877 884.

Parker, G. H.(1939). General anesthesia by cooling. Proceedings of the Society for Experimental
Biology and Medicine 4, 186 187.

Pottinger. T. G. and Calder, G. M.(1995). Physiological stress in fish during toxicological procedures: a potentially confounding factor, Environmental Toxicology and Water Quality 10, 135 146.

Pottinger, T. G. - Carrick, T. R. and Yeomans, W. E.(2002). The three-spined stickleback as an environmental sentinel: effects if stressors on whole-body physiological indices, Journal of Fish Biology 61, 207 229.

Pottinger, T. G. - Moran, T. A. and Cranwell, P. A.(1992). The biliary accumulation of corticosteroids in rainbow trout, Oncorhynchus mykiss, during acute and chronic stress, Fish Physiology and Biochemistry 10, 55 66.

Raabo, E. and Terkildsen, T. C.(1960). On the enzymatic determination of blood glucose, Scandinavian Journal of Clinical \& Laboratory Investigation 12, 402 407.

Redding, J. M. and Schreck, C. B.(1983). Influence of ambient salinity on osmoregulation and cortisol concentration of yearling coho salmon during stress, Transactions of the American Fisheries Society $112,800 \sim 807$.

Schreck, C. B.(1981). Stress and compensation in teleostean fishes: response to social and physical factors. In: A.D. Pickering (Ed.), Stress and Fish, Academic Press, London, 13, 295 321.

Schreck, C, B. - Contreras-Sanchez, W. and Fitzpatrick, M. S.(2001). Effects of stress on fish reproduction, gamete quality, and progeny, Aquaculture 197, 3 24.

Song, H. Y. - Nam, Y. K. - Bang, I. -C. and Kim, D. S.(2009a). Early gonadogenesis and sex differentiation of marine medaka, Oryzias dancena (Beloniformes; Teleostei), Korean Journal of Ichthyology 21, 141 148, (in Korean with an English abstract).

Song, H. Y. - Nam, Y. K., Bang, I. -C. and Kim, D. S.(2009b). Embryogenesis and early ontogenesis of a marine medaka, Oryzias dancena, Korean Journal of Ichthyology 21, 227 238, (in Korean with an English abstract).

Summerfelt, R. C. and Smith, L. S.(1990). Anesthesia, surgery, and related techniques, In: Schreck, C.B. and Moyle PB (Eds.) Methods for Fish Biology, American Fisheries Society, Bethesda, MD, USA. 
Changing Temperature Affects Anesthetic Effects and Physiological Stress Responses in Marine Medaka, Oryzias dancena

213 272.

Williamson, R. M. and Roberts, B. L.(1981). Body cooling as a supplement to anaesthesia of fishes, Journal of the Marine Biological Association of the UK 61, 129 132.

- 논문접수일 : 2014년 01월 29일

- 심사완료일 : 1차 - 2014년 02월 27일

- 게재확정일 : 2014년 03월 07일 